\title{
Heart transplants for patients with Chagas' heart disease
}

\author{
Heart Institute, Hospital das Clínicas, \\ Faculdade de Medicina da Universidade de São Paulo - São Paulo, Brazil
}

\begin{abstract}
The role of heart transplants for treating Chagas' heart disease is not quite clear. Immunosuppression could lead to resurgence of T. cruzi infection with acute or chronic damage to the allograft. There are few publications regarding this issue. Thus we reported the follow-up of 18-patients with Chagas' heart disease submitted to orthotopic heart transplants from 1985 to 1993 at The Heart

Institute. The patients were in functional class IV or III, or II, with sustained ventricular tachycardia episodes. The mean left ventricular ejection fraction was $25 \pm 9 \%$ and the mean right ventricular ejection was $22 \pm 6 \%$ (MUGA). Immunosuppression was based on cyclosporin, azathioprine and corticosteroids. For specific post-transplant monitoring of $T$. cruzi infection, blood tests were performed (examination of blood or leukocyte concentrate, Giemsa-stained blood smears, blood culture, xenodiagnosis, mouse inoculation) and tissue biopsy (skin or myocardium). In addition, complement fixation hemagglutination and

immunofluorescence assays were performed. T. cruzi parasitemias were detected in 18 circumstances in 13 patients. Resurgence of Chagas' disease was diagnosed in 11 circumstances in 5 patients. Fever, subcutaneous nodules and myocarditis predominated in these episodes. All episodes of parasitemia and Chagas' disease resurgence were successfully treated with benzonidazole. All surviving patients had normal cardiac function despite left ventricular function worsening during some myocarditis episodes. Neoplasias were important findings and 3 patients developed lymphoproliferative disease, 2 developed Karposi's sarcoma and 1 patient developed skin cancer. The survival rates at 4 and 12 months were $83 \%$ and $49 \%$ respectively. The survival of patients who underwent heart transplants from August 1991 to April 1993 was $100 \%$ at 4 months and $75 \%$ at 12 months. Heart transplants for Chagas' heart disease may be associated with episodes of parasitemia and a reoccurrence of episodes of Chaga's disease. The survival of heart transplanted patients has improved when associated with lower doses of cyclosporins and thus, fewer resurgences of the disease.
\end{abstract}

UNITERMS: Trypanosoma cruzi.

A t the Instituto do Coração of the Hospital das Clínicas, part of the São Paulo University, in approximately $18 \%$ of patients suffering from congestive heart insufficiency which was not responding to clinical treatment, and who were sent to the hospital as

\section{Address for correspondence:}

Edimar Alcides Bocchi

Rua Oscar Freire, 2077 - Apto. 161

São Paulo - SP - Brasil - CEP 05409-011 possible heart transplant candidates, Chagas' disease was the cause of the myocardiopathic etiology (21). Studies have pointed to high mortality rates by cardiac insufficiency in Chagas' disease, notwithstanding the recent progress in treating cardiac insufficiency with enzyme inhibitor angiotension conversion drugs (6).

Currently, heart transplant is the procedure of choice in surgical treatment for a selected group of patients with intractable cardiac insufficiency but Chagas' myocardiopathy may limit this procedure. The presence of chronic $T$. cruzi infection, and its possible pathogenic role in cardiac disease, has been considered by some 
clinical centers as counter-productive when related to the use of transplants $(1,13)$. Trypanosoma cruzi infection can reoccur acutely in the patient, putting the transplanted heart at risk. Apart from this chronic myocardiopathy can appear during heart transplantation, influenced or not by the use of immunosuppressant drugs. Notwithstanding these restrictions, heart transplants have been used within our institute as a therapeutic procedure for a group of selected patients, non-responsive cardiac insufficient carriers suffering the results of Chagas' disease, due mainly to the initial results.

\section{Table 1}

Studies normally carried out to determine suitability for heart transplant

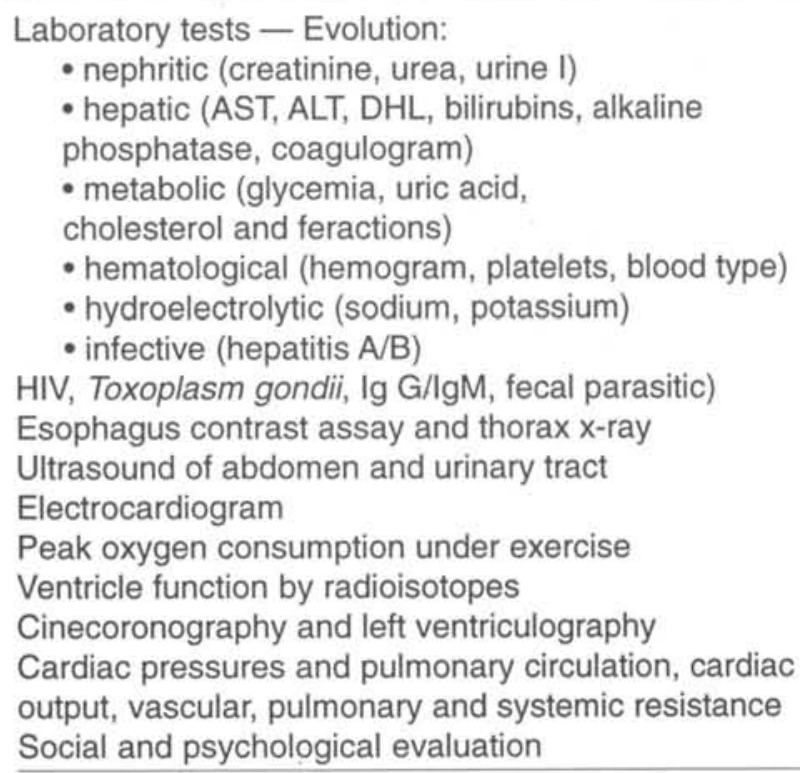

AST $=$ aminotransferase aspartate, $\mathrm{ALT}=$ aminotransferases alanine, $\mathrm{DHL}=$ lactic dehydrogenase, $\mathrm{HIV}=$ acquired immunodeficiency syndrome virus, parasitic $=$ parasitological test.

\section{RECEPTOR SELECTION}

The selection of receptors for heart transplanting is based on whether patients will probably undergo an important improvement in their symptoms, in their functional capabilities and in their life expectancy after the procedure. However, controlled studies which compare post heart transplant results with those results of clinical treatment have yet to be carried out, even less so where Chagas' disease is concerned. Because of this, precise patient selection is limited. Patients to be potentially indicated for a heart transplant will be those that persistently show cardiac insufficiency in functional class III or IV (according to the New York Heart Association's categories), accentuated suffering of heart function, and functional limitations coupled with low quality of life. Apart from this, patients with drug therapy-resistant sustained ventricular tachycardia episodes and with a guarded prognosis may be candidates for heart transplanting.

Between March 1985 and April 1993 one hundred and fourteen patients suffering from congestive cardiac insufficiency or recurring episodes of sustained ventricular tachycardia were subjected to orthotopic heart transplant at the Heart Institute. Among these patients eighteen (16\%) had Chagas' disease as the myocardiopathic etiology (3). Chagas' myocardiopathy was the third etiology in importance as the cause of cardiac insufficiency. Table 1 lists the exams commonly carried out during the patient selection process for heart transplants.

For these patients the average value for the fraction of left ventricle ejection as determined by the radioisotopic method was $25 \pm 9 \%$. In thirteen of these patients the average value for the fraction of the right ventricle was also determined, and was found to be $22 \pm 6 \%$. During echocardiographic evaluation the average value of the fraction of left ventricle ejection was $36 \pm 10 \%$, with a final left ventricle diastolic diameter of $74 \pm 9 \mathrm{~mm}$. The criteria used for indicating or counter indicating patient selection are the same for differing Chagas' disease etiologies. Patients were excluded for heart transplants if the following were present: guarded prognosis of systemic disease, irreversible pulmonary, renal or hepatic disease, accentuated peripheral cerebral vascular disease, insulindependant diabetes with neurological complications, retinopathy and nephropathy; active infection; neoplasia; pulmonary hypertension with a fixed pulmonary vascular resistance greater than 6 units on the Wood Scale; recent pulmonary infarct or embolism; diverticulitis or active diverticulitis; active peptic ulcer; advanced osteoporosis; social or psychological limitations; drug or alcohol abuse, and advanced age. Apart from these, patients who are carriers of megaesophagus or megacolon were also excluded. The diagnosis for heart transplants for sufferers of Chagas' cardiopathy may be confirmed by the tests numbered under Table 2. 


\section{Table 2 \\ T. cruzi infection monitoring}

\section{IMMUNODEPRESSOR MEDICATION}

Nowadays the triple scheme of corticosteroids azathioprine and cyclosporins has been the most used after heart transplants.

At our institution lower doses of cyclosporins have been associated with a lower incidence in the disease's resurgence. It is still not clear if the use of a double scheme involving corticosteroids and azathioprine is better than the triple scheme. The patient should, however, receive the largest possible tolerable degree of immunodepression.

\section{INFECTION RESURGENCE by TRYPANOSOMA CRUZI (Table 3)}

Patients who have undergone heart transplants at our institution have commonly had a resurgence of Chagas' disease or parasitemia. During the first six months and first year of evolution after transplanting, the linear rate of parasitemia has been 0.13 and 0.09 episodes per patient per month, while resurgence of Chagas' disease has been 0.03 episodes for both, per patient per month.

Among serological tests only hemagglutination showed titer changes on 12 occasions during episodes of parasitemia or Chagas' disease resurgence.

Resurgence occurred 12 times in 5 patients. Myocarditis was diagnosed nine times, and four patients showed a worsened transient of the left ventricle ejection factor. Two patients had at least two myocarditis episodes. After specific treatment with benzonidazol these manifestations regressed. In general, the clinical state followed myocarditis. In just one patient with a characteristic clinical state xenodiagnosis was negative. Positive xenodiagnosis occurred prior to Chagas' disease resurgence manifestations in four patients.

However, the clinical manifestations present at resurgence of Chagas' disease were different to those classically described in the disease's acute form (24).

Fever, myocarditis and subcutaneous nodules were predominant in Chagas' disease resurgence after heart transplanting while the disease's acute phase was characterized by fever, inoculation chagoma, lymphadenopathy, cardiac alterations. In $T$. cruzi infections

Table 3

Summary of Chagas' disease monitoring results after heart transplant, covering all episodes of parasite detection or the disease's resurgence by $T$. cruzi.

\begin{tabular}{|c|c|c|c|c|c|c|c|c|c|c|c|c|c|c|c|c|c|c|c|c|c|}
\hline 당 & \multicolumn{14}{|c|}{ Results during 22 episodes } & \multicolumn{7}{|c|}{ Total } \\
\hline Xeno + & - & - & - & - & + & + & + & + & + & + & - & - & + & + & + & + & + & + & + & + & +15 \\
\hline $\mathrm{RS}+$ & + & - & - & - & + & + & + & + & + & - & - & - & - & - & - & + & + & + & + & + & +12 \\
\hline $\mathrm{QC}+$ & + & - & - & - & + & - & + & + & - & - & - & - & + & - & - & - & - & - & - & - & -5 \\
\hline Ite + & + & + & + & + & - & - & + & + & - & - & + & + & + & - & - & - & - & - & - & - & -9 \\
\hline Total & 3 & 1 & 1 & 1 & 3 & 2 & 4 & 4 & 2 & 1 & 1 & 1 & 3 & 1 & 1 & 2 & 2 & 2 & 2 & 2 & 2 \\
\hline
\end{tabular}

Xeno $+=T$. cruzi detected by in vivo xenodiagnosis, RS Serological reaction,

$\mathrm{QC}=$ symptoms and signs are present, Ite $=$ myocarditis 
the influence of each immunodepressor medication is not completely understood and trial data is still controversial. Mice receiving high cyclosporin dosages before acute $T$. cruzi infection suffer more intense parasitemia, notwithstanding the cyclosporin's antiparasitic effect, when compared to the control group. However, mice which received cyclosporins after infection had similar parasitemia to the control group (18).

Immunosuppression combined with the use of cyclosporins and corticosteroids caused an increase in Chagas' disease's intensity in experimentally infected mice (23). In immunosuppressed humans after renal transplanting, the resurgence of the infection is not routinely found. Some teams have not found reactivated $T$. cruzi infection after renal transplants in patients without cardiopathy $(2,16,17)$. But an acute form of Chagas' disease developed after renal transplanting in non Chagas' disease carriers who received kidneys from infection carriers. Drugs used for immunosuppression were azathioprine and corticosteroids and the general clinical state was not serious, and responded well to treatment using benzonidazol (5). Other researchers have described a resurgence of the infection after renal transplanting, sometimes including damage to the central nervous system $(14,19)$. $T$. cruzi infection resurgence has also been observed during chemotherapy when treating acute lymphocytic leukemia, attributed to modifications in cellular immunity (12,25). In AIDS carriers, infection resurgences with neurological manifestation have been described (7). Concerning resurgence after heart transplanting, the results of preliminary studies carried out at our institution suggest that pulsotherapy using corticoids may predetermine the infection resurgence by Trypanosoma cruzi (26). Resurgence of Chagas' disease with damage to the skin and myocardium, accompanied by fever has also recently been described as occurring among three of six patients after heart transplanting $(10,15)$. Furthermore, anti Trypanosoma cruzi, drugs such as benzonidazol have only proved to be effective in reducing parasitemias without eliminating the parasites (11) and in experimental studies have not prevented acute myocarditis from progressing to chronic Chagas' myocardiopathy (28).

\section{NEOPLASIAS}

Three patients developed lymphoproliferative disease in the third, sixth and seventh month of evolution. Furthermore, two of the patients developed Kaposi's sarcoma during the seventh and sixtieth months and one patient, skin spinocellular carcinoma. In another patient the lymphoproliferative disease was diagnosed incidentally during the anatomopathological examination. The organs affected by the lymphoproliferative disease were: small intestine (one patient); lungs, skin and liver (one patient); skin and small intestine (one patient). A high incidence of neoplasias was noted. Neoplasia was the primary cause of death in another two patients and a contributing factor in another. The incidence of neoplasia can be considered as being very high when compared with other patients undergoing transplants by other etiologies using the same immunosuppression treatment. The development of neoplasias and lymphomas has been related to the intensity of immunosuppression, to the infection by the EpsteinBarr-virus and prolonged antigenic stimulation of the lymphoreticular system by the organ receiver $(8,9)$.

However, the greater incidence of neoplasias suggests the presence of additional factors in Chagas' disease carriers, such as that contributed by the use of benzonidazol (29) and immunological disturbances associated with Chagas' disease. In experimental studies the use of benzonidazol has been associated with the appearance of lymphomas in up to $30 \%$ of rats with Chagas' disease. It is not known whether in humans the incidence of lymphomas increases with the use of benzonidazol, but this drug may cause damage to cellular immunity (27). Concerning the immunological aspects of Chagas' disease, experimental trials demonstrate that $T$. cruzi infection induces immunological disturbances at cellular and humoral levels.

\section{MORTALITY (Figures 1 and 2)}

Of 18 patients submitted to a heart transplant at the Heart Institute, 11 are still alive after 4 to 96 months, in good clinical condition and capable of carrying out their normal activities, including work. Survival rates after heart transplanting found in the $1 \mathrm{st}, 4 \mathrm{th}, 8$ th and 12 th months and after the first year were $89 \%, 83 \%, 63 \%, 54 \%$ and $54 \%$ respectively. Patients who underwent transplants in the period from August 1991 to April 1993 show survival in the $1 \mathrm{st}, 3 \mathrm{rd}, 6$ th, 9 th and 12 th months as being $100 \%$, $100 \%, 100 \%, 100 \%$ and $75 \%$. Therefore, when comparing survival of patients submitted to heart transplants as from August 1991 with the whole group an expressive improvement in survival in the first year is to be found. The cyclosporin dosage reduction used in the latter period may be one of the responsible factors, together with 


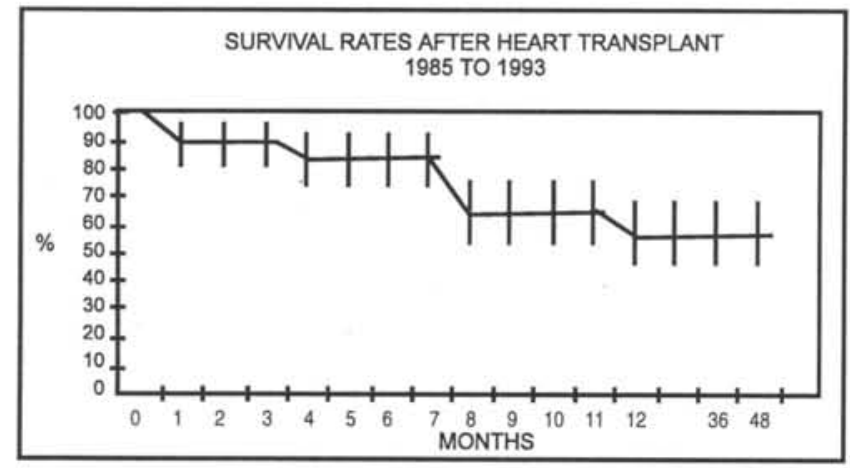

Figure 1: Survival rate of the patients submitted to cardiac transplant at the Instituto do Coração from September 1985 through June 1991.

improved knowledge regarding Chagas' disease, and others.

\section{CLINICAL EVOLUTION AFTER HEART TRANSPLANTING}

Apart from the greater incidence of neoplasias and the resurgence of Chagas' disease during the initial phase of post heart transplants due to Chagas' disease, the clinical interoccurrences have been similar to those described for patients of other etiologies.

\section{CONCLUSION AND CLINICAL IMPLICATIONS}

Ever since Carlos Chagas described the chronic cardiac form of Chagas' disease in 1911, as having Leichmanoid agglomerates within the cardiac fibers of the histopathological sections of the myocardium, obtained

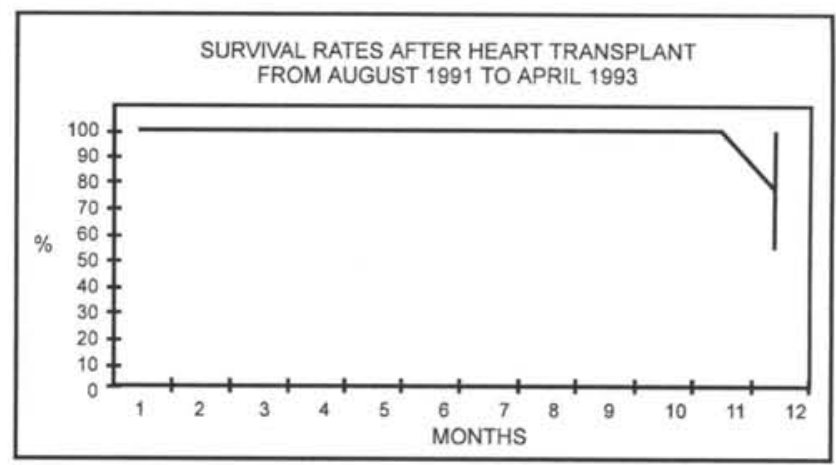

Figure 2. Survival rates during the first year of patients who underwent heart transplants from August 1991 to April 1993.

from necropsy, therapeutic options have been searched for which could benefit the carriers of this sickness. The surgical success of heart transplants for sufferers of cardiac insufficiency due to other etiologies has made the challenge of undertaking this surgery in Chagas' disease carriers possible. However, inherent physiopathological aspects of the disease have modified some of the results obtained up till then regarding heart transplants in patients with other etiologies. Thus, the results shown were influenced in a very expressive manner by persistent presence of $T$. cruzi, red believed to be of little importance in the pathogenesis of chronic Chagas' myocardiopathy. Heart transplants were associated with frequent episodes of parasitemia and the resurgence of Chagas' disease. Parasitemia was observed in greater proportion, and myocarditis was found to be common in the disease resurgences. Heart function remained normal during evolution of heart transplanting in spite of the incidence of myocarditis. We also noted an unsatisfactory response to $T$. cruzi chronic infection from the use of available drugs such as benzonidazol. The results also illustrate the development of the use of the procedure in Chagas' myocardiopathy, passing from an initial distressing phase to a more recent phase of improved results. 


\section{RESUMO}

A indicação do transplante cardiaco para o tratamento da miocardiopatia chagásica apresenta controvérsias. A infecção pelo $T$. cruzi, influenciada pelo uso de drogas imunossupressoras, poderia recorrer aguda ou cronicamente no paciente, comprometendo o enxerto.

Revisamos os resultados do transplante cardiaco para o tratamento da doença de Chagas. Entretanto, devido à limitada presença de publicaçōes, descrevemos a evolução de 18 pacientes portadores de miocardiopatia chagásica após o transplante cardíaco ortotópico realizado no periodo de setembro de 1985 a abril de 1993 no Instituto do Coração.

Os pacientes estavam em classe funcional III ou IV, ou II com episódios de taquicardia ventricular sustentada. O valor médio da fração de ejeção do ventrículo esquerdo por radioisótopos foi de $25 \pm 9 \%$ e a do ventrículo direito foi de $22 \pm 6 \%$. A ciclosporina, a azatioprina e os corticóides foram as drogas básicas utilizadas para imunossupressão. A reativação da infecção pelo T. cruzi foi monitorizada periodicamente por métodos para detecção do parasita no sangue (creme leucocitário, esfregaço, cultura, xenodiagnóstico, inoculaçāo em camundongos) e nos tecidos por análise de biópsia de miocárdio ou pele. Além disso, foram realizadas reaçōes de fixaçāo de complemento, hemaglutinaçāo e imunofluorescência. Parasitemia foi detectada em 18 oportunidades em 13 pacientes. A reativaçāo da doença de Chagas foi diagnosticada em 11 oportunidades em cinco pacientes. As manifestações mais comuns foram febre, nódulos subcutâneos e miocardite. Os episódios foram tratados com benzonidazol com sucesso. A função cardíaca manteve-se normal na evolução, apesar do comprometimento transitório durante episódios de miocardite em alguns pacientes. A presença de neoplasias foi uma complicação importante com o aparecimento de doença linfoproliferativa em três pacientes, sarcoma de Kaposi em dois e carcinoma espinocelular em um. A sobrevida foi de $83 \%$ no quarto mês e $54 \%$ no $12^{\circ}$ mês. A sobrevida no grupo submetido ao transplante de agosto de 1991 a abril de 1993 foi de $100 \%$ no quarto mês e de $75 \%$ no final do primeiro ano.

Os resultados demonstram que o transplante cardiaco foi associado a freqüentes episódios de parasitemia e reativaçāo da doença de Chagas. Em período mais recente a mortalidade diminuiu, associada à redução das doses utilizadas de ciclosporina e a menor incidência de reativação da doença de Chagas.

\section{REFERENCES}

1. ACOSTA, A.M. \& SANTOS-BUCH, C.A. - Autoimmune myocarditis induced by Trypanosoma cruzi. Circulation 6:1255-61, 1985.

2. ARTEAGA, J.; MASSARI, P.U.; GALLI, B.; GARZON, M.F. \& ZLOCOWSKY, J.C. - Renal transplantation and Chagas'disease. Transplant Proc 24: 1900-1, 1992.

3. BOCCHI, E.A. - Análise dos resultados do transplante cardíaco para tratamento da miocardiopatia chagásica. São Paulo, Universidade de São Paulo, 1993. p. 1-65.

4. BOCCHI, E.A.; BELLOTTI, G.; UIP, D. et al. - Long-term follow-up after heart transplantation in Chagas' heart disease. Transpl Procced 25:1329-30, 1993.

5. CHOCAIR, P.R.; AMATO-NETO, V.; SABBAGA, E. \& TORRECILLAS, P.H. - Aspectos clínico-diagnósticos relativos à fase aguda da doença de Chagas, em pacientes submetidos a transplante de rim e imunodeprimidos. Rev Soc Bras Med Trop 18: 43-45, 1985.

6. COHN, J.N. \& RECTOR, T.S. - Prognosis of congestive heart failure and predictors of mortality. Am J Cardiol 62:25A30A, 1988.
7. GLUCKSTEIN, D.; CIFERRI, F. \& RUSKIN, J. Chagas'disease: another cause of cerebral mass in the acquired immunodeficiency syndrome Am J Med 92: 42932, 1992.

8. GRIFFTH, B.P.; HARDESTY, R.L.; THOMPSON, M.E.; DOMMER, J.S. \& BOHMSON, H.T. - Cardiac transplantation : The Pittsburg experience. J Heart Transplant 2: 251-6, 1983.

9. HANTO, D.; FRIZZERA, G.; GAIL-PECZALSKA, K. et al. - Epstein-Barr virus induced B-cell lymphoma after renal transplantation. N Engl J Med 306: 913-8, 1982.

10. KIRCHOHHOFF, L.V. - American trypanosomiasis (Chagas'disease) - a tropical disease now in the United States. N Engl J Med 329: 639-44, 1993.

11. KIRCHOHHOFF, L.V. - Is Trypanosoma cruzi a new threat to our blood supply? Ann Intern Med 11:773-5, 1989.

12. KOHL, S.; PICKERING, L.K.; FRANKEL, L.S. \& YAEGER, R.G. - Reactivation of Chagas'disease during therapy of acute lymphocytic leukemia. Cancer 50: 827-8, 1982.

13. LARANJA, F.S.; DIAS, E.; NOBREGA, G. \& MIRANDA, A. - Chagas'disease: a clinical, epidemiologic and pathologic study, Circulation 14:1035-60, 1956. 
14. LEIGUARDA, R.; RONCORONI, A.; TARATUTO, A.L.; JOST, L.; NOGUES, M. \& FREILIJ, H. - Acute CNS infection by Trypanosoma cruzi (Chagas'disease) in immunosuppressed patients. Neurology 40:850-1, 1990.

15. LIBOW, L.F.; BELTRANI, V.P.; SILVERS, D.N. \& GROSMAN, M.E. - Post-cardiac transplant reactivation of Chagas'disease diagnosed by skin biopsy. Cutis 48: 37-40, 1991.

16. LOPEZ-BLANCO, O.A.; CAVALLI, N.H.; JASOVITCH, A.; GOTLIEB, D. \& GONZALEZ-CAPPA, S. Chagas'disease and kidney transplantation - follow-up of nine patients for 11 years. Transplant Proc 24:3089-90, 1992.

17. LUDERS, C.; CAETANO, M.A.; IANHEZ, L.E.; FONSECA, J.A. \& SABBAGA, E. - Renal transplantation in patients with Chagas'disease: a long-term follow-up. Transplant Proc 24:1878-9, 1992.

18. MCCABE, R.E.; REMINGTON, J.S. \& ARAUJO, R.G. - In vivo and vitro effects of cyclosporine on Trypanosoma cruzi. Am J Trop Med Hyg 34: 861-5, 1985.

19. MOCELIN, A.J.; BRANDINA, L.; GORDAN, P.A.; BALDY, J.L. \& CHIEFFI, P.P. - Immunosuppression and circulating Trypanosoma cruzi in a kidney transplant recipient. Transplantation 23:163, 1977.

20. MUDGE, G.H.; GOLSTEIN, S.; ADDONIZIO, L.J. et al. Task Force 3: recipient guidelines/prioritization. J Am Coll Cardiol 22: 21-31, 1993.

21. NASTARI, L.; FREITAS, H.F.G.; MANSUR, A.J. et al. Mortalidade de doentes em avaliação para tratamento cirúrgico de insuficiência cardíaca. Rev Soc Cardiol Est São Paulo 3:27, 1993.

22. O'CONNEL, J.B.; BOURGE, R.C.; CONSTANZONORDIN, M.R. et al. - Cardiac transplantation: recipient selection, donor procurement, and medical follow-up. A statement for health professional from the committee on cardiac transplantation on the council on clinical cardiology, American Heart Association. Circulation 86:1061-79, 1991.

23. OKUMURA, M.; AMATO-NETO, V.; KITAGAWA, M.M. et al. - Atividade terapêutica do benzonidazol em camundongos infectados pelo Trypanosoma cruzi e imunodeprimidos pela associação de ciclosporina com prednisona. Rev Hos Clin Fac Med São Paulo 45: 260-1, 1990.

24. RASSI, A. - Clínica: Fase aguda. In: Brener, Z. \& Andrade, Z. ed. Trypanosoma cruzi e doença de Chagas. Rio de Janeiro, Guanabara Koogan, 1979. p.249-64.

25. RIVERO, I.; MORAVENICK, M.; MORALES, J.; GOMEZ, M. \& DE ROSAS, J.M. - Chagas'disease - another hazard in acute leukemia. N Engl J Med 290: 285, 1974.

26. STOLF, N.A.G.; HIGUSHI, L.; BOCCHI, E.A. et al. - Heart Transplantation in patients with Chagas'disease cardiomyopathy. J Heart Transplant 6: 307-12, 1987.

27. TEIXEIRA, A.; JOBUR, E.; CONDOBA, J.C.; SOUTOMAIOR, J \& SOLONZANO, E. - Alteração da resposta imune para células durante o tratamento com benzonidazole. Rev Soc Bras Trop 16: 11-23, 1983.

28. TEIXEIRA, A.R.; CUNHA-NETO, E.; RIZZO, L.V. \& SILVA, R. - Trypanocidal nitroarene treatment of experimental Trypanosoma cruzi infection does not prevent progression of chronic-phase heart lesions in rabbits (letter). J Infect Dis 162:1420, 1990.

29. TEIXEIRA, A.R.L.; CÓRDOBA, J.C.; SOUTO-MAIOR, I. \& SOLÓRZANO, E. - Chagas'disease: lymphoma growth in rabbits treated with benzonidazole. Am J Trop Med Hyg 43:146-58, 1990. 